\title{
DE CONTADOR A PROFESSOR: A TRAJETÓRIA DA DOCÊNCIA NO ENSINO SUPERIOR DE CONTABILIDADE MARCOS LAFFIN SANTA CATARINA: IMPRENSA UNIVERSITÁRIA
}

\author{
"REVIEW OF THE BOOK ENTITLED: "FROM ACCOUNTANT TO \\ TEACHER: THE TRAJECTORY OF TEACHING ACCOUNTABILITY \\ IN HIGHER EDUCATION SETTINGS BY MARCOS LAFFIN. SANTA \\ CATARINA STATE: UNIVERSITY PRESS".
}

\section{" RESEÑA DEL LIBRO "DE CONTABLE A PROFESOR: LA TRAYECTORIA DE LA DOCENCIA EN LA ENSEÑANZA SUPERIOR DE CONTABILIDAD, POR MARCOS LAFFIN. SANTA CATARINA: PRENSA UNIVERSITARIA".}

\begin{abstract}
VALDÉRIO FREIRE DE MORAES JÚNIOR
Professor Assistente na Universidade Federal da Paraíba. Graduado em Ciências Contábeis (UFRN), Especialista em Controladoria e Gestão de Negócios (UFRN) e Mestre em Ciências Contábeis pelo Programa Multiinstitucional e Inter-regional da UnB/UFPB/UFRN valderio@ccsa.ufpb.br
\end{abstract}

O livro "De contador a professor: a trajetória da docência no ensino superior de Contabilidade", de Marcos Laffin, lançado em 2005, em Florianópolis, traz uma autobiografia do autor, traçando o caminho trilhado quando professor do curso de Ciências Contábeis, e um relato de um profissional que abraçou a carreira docente por escolha própria.

O objetivo principal dessa obra é apresentar aos leitores, como bem diz o autor, "a compreensão dos fundamentos epistemológicos da organização do trabalho realizado pelo professor de Contabilidade no ensino superior, buscando características próprias através de componentes científicos que fazem parte do processo de ensino".

O trabalho qualitativo feito por Laffin tem como base o professor como sujeito humano e do trabalho, pelo fato de essa condição humana promover relações sociais, históricas 
e culturais. É fundamentado também em uma pesquisa empírica feita em quatro Instituições de Ensino Superior, com 28 professores todos formados em Ciências Contábeis e que desenvolvem atividades no ensino superior em disciplinas do curso de Contabilidade.

O autor afirma que ensinar exige do docente uma responsabilidade em ter domínio de conteúdos específicos e de saberes de formação humana, tendo, acima de tudo, métodos adequados para auxiliar na solidariedade humana. Portanto, esse senso no trabalho coletivo faz do professor de Contabilidade um profissional com um entendimento crítico e evolutivo no seu campo de trabalho.

O livro é dividido em cinco capítulos, além da apresentação, introdução, conclusões e bibliografia. Logo na apresentação, o autor define bem a intenção da sua obra, que é relatar aos leitores toda uma trajetória de um profissional, no caso contador, que optou por ser docente. $\mathrm{Na}$ introdução, o autor comenta sobre os contextos sociopolítico, econômico e cultural nos quais a sociedade se encontra atualmente, para depois adentrar no curso de Ciências Contábeis e daí no trabalho do professor de Contabilidade.

Ainda na introdução, Laffin descreve o contador nas organizações, através de um novo contexto, as exigências para esse profissional na atualidade e quais são as bases na formação do professor de Contabilidade, mostrando a relevância e a originalidade do estudo realizado. O autor também mostra como construiu a metodologia no seu estudo, os pressupostos da pesquisa, a delimitação, os sujeitos, os instrumentos e os limites do estudo.

No Capítulo 1, intitulado "o ser humano e o trabalho: concepções e relações sociais", Laffin comenta sobre o ser humano de uma forma geral, através da condição humana, que seria sair da transgressão do instinto para o ser de reflexão e ação, fortalecendo o entendimento por meio da compreensão, da cultura, da multiplicidade e do sujeito como território do mundo humano.

O trabalho como produto humano: complexo desafio de produzir-se humano é o título do Capítulo 2. Nele, o autor descreve o trabalho na realidade atual, quando faz comentários sobre apreensão de alguns elementos constitutivos, como a profissionalização do sujeito trabalhador no seu trabalho formal ou informal, criando uma produção flexível, ao gerar um novo colapso no ambiente profissional. As organizações contemporâneas se transformam em organizações possíveis vencendo desafios para diminuir barreiras.

Já no Capítulo 3, intitulado "O conhecimento contábil e a legislação do ensino", o autor discute a Contabilidade na legislação do ensino comercial e sobre alguns aspectos intervenientes no currículo do curso superior de Contabilidade. Laffin comenta que, ao verificar a literatura específica, a história humana está vinculada à área contábil e que no Brasil, desde 1945, foi fixado o currículo em conjunto com a criação desse curso em nível superior.

O contador que forma o professor de Contabilidade é o tema do Capítulo 4 do livro. As discussões feitas pelo autor abrangem o perfil do universo pesquisado, as circunstâncias do contador vir a ser professor de Contabilidade, a formação do professor de Contabilidade 


\section{repc}

De Contador a Professor: A Trajetória da Docência no Ensino Superior de Contabilidade

e os significados de ser professor de Contabilidade no ensino superior. Por meio de depoimentos selecionados, o autor trabalha com a representação do coletivo, apresentando de forma sintética o universo dos professores pesquisados.

Ao final, o título do Capítulo 5 traz a prática da docência no ensino superior de Contabilidade. $\mathrm{O}$ autor identifica as concepções epistemológicas relacionadas ao ensino-aprendizagem e às categorias metodológicas vinculadas à organização do trabalho pedagógico do professor de Contabilidade. Laffin explica que o conjunto de depoimentos e das falas registradas auxiliaram em um melhor aprofundamento do questionário.

Ao encerrar o livro, o leitor pode constatar que a leitura é pertinente e apropriada à área de ensino, pois a investigação feita pelo autor não é restrita e necessária apenas aos professores de Ciências Contábeis, mas por todas as pessoas que optaram a docência como profissão. 